\title{
Institutional challenges for effective governance of consumptive wildlife tourism: case studies of marine angling tourism in Iceland and Norway
}

\author{
Maria-Victoria Solstrand
}

Correspondence:

mvsolstrand@gmail.com

Norwegian College of Fishery

Science, Faculty of Biosciences,

Fisheries and Economics, UiT The

Arctic University of Norway,

NO-9037 Tromsø, Norway

\section{Springer}

\begin{abstract}
Good governance of consumptive wildlife tourism, a complex socio-ecological system, requires finding the right balance between natural resource and tourism management. Fishing takes the lead globally as the most popular product offering within consumptive wildlife tourism, and both Iceland and Norway offer a marine angling tourism product. The two countries offer similar pristine Arctic fjord topography and similar fish species; but the management strategies are very different. Iceland's management strategy for marine angling tourism prioritizes ecosystem-based management of the fish as a living resource, and requires a full accounting of all statistics related to marine angling tourists' activities. Norway's strategy relies on estimates of key statistics such as total seasonal catch, and the regulations put the burden of accountability primarily on the tourists. Using data from a multiple case study analysis of marine angling tourism in Iceland and Norway, the differences in governance inter-dynamics are examined using a theoretical model developed to analyse a complex socio-ecological system as an institution. This paper analyses how the differing management strategies influence institutional function, conflict creation and mitigation. Special focus is placed on the impacts of non-compliance by the tourists. This study demonstrates how such a model can serve as a tool to perform an analysis of a socio-ecological system in order to better understand institutional inter-dynamics, thereby assisting in the creation of a more effective governance strategy.
\end{abstract}

Keywords: Marine angling tourism; Consumptive wildlife tourism; Sustainable tourism management; Common pool resources; Institutional pillars; Interactive fisheries governance; Socio-ecological system; Natural resource management; Iceland; Norway

\section{Introduction}

Consumptive wildlife tourism is a specialized niche sector of tourism (Lovelock 2008) which has the potential to create institutional conflicts, especially with regard to natural resource management. Fishing takes the lead globally (Bauer and Herr 2004) as the most popular product offering within this tourism niche. Remote coastal communities in Iceland and Norway serve as host destinations for marine angling tourism $(\mathrm{MAT})^{\mathrm{a}}$, a popular and expanding form of consumptive wildlife tourism in the Arctic fjords. These small communities have relied on the fish in the fjords for hundreds of years as part of a long-standing sea fishing tradition. With the rise in MAT, the locals must now share "their" fish with foreign tourists, potentially creating scenarios for 
tourism-related conflicts (Arlinghaus 2005; Yang et al. 2013; Butler 1974; Robinson 1999; Budowski 1976). Conflict, in this context, is defined as a serious incompatibility between two or more opinions, principles, or interests ${ }^{\mathrm{b}}$ - referring here only to sources of conflict behaviour (e.g. divergence of interests or values), not the conflict behaviour itself (e.g. acts of violence) (Pruitt 1998). Conflict can have a positive social function and is not necessarily an indicator of dysfunctionality from a governance perspective. A certain degree of conflict is an essential element in group dynamics and group formation, and is considered a learning and growth opportunity for institutions (Coser 1956), but this is in part dependent upon how the institution adapts to resolve or mitigate emergent conflicts.

Sustainable tourism scholars have identified that reconciling the conflicts, and finding balance between the socio-economic benefits of tourism development and sustainable use of natural resources are necessary pre-requisites for sustainable tourism development (Briassoulis and van der Straaten 1992; Farrell and Twining-Ward 2004; Gössling 2002; Hall 2001; Briassoulis 2002; McKercher 1993; Robinson 1999). However, natural resource management policies related to tourism development are often made outside the tourism domain (Bramwell 2011; Hall 2008), for example within fisheries management. Attempting to govern tourism development without consideration of the living resources being consumed; or governing the living resources without consideration of how tourism development is affected, are both missing a critical component in the overall analysis of sustainability.

Fish species common to both Northern Norway and the Western Fjords of Iceland are cod (Gadus morhua); Atlantic halibut (Hippoglossus hippoglossus); wolffish (Anarhichas spp); anglerfish (Lophius piscatorius); and haddock (Melanogrammus aeglefinus). Saithe (Pollachius virens), redfish (Sebastes spp.), and tusk (cusk) (Brosme brosme) are part of the fishing experience in Northern Norway but are not typically found in the Western Fjords. In the commercial scale fisheries, Iceland and Norway are ranked similarly with regard to management. In a study by Pitcher et al. (Pitcher et al. 2009; Pitcher et al. 2006; Ward et al. 2002) to evaluate progress in implementing ecosystembased management (EBM) of commercial fisheries in 33 countries (in connection with evaluation of global compliance with the UN Code of Conduct for Responsible Fisheries), Norway was listed among the top six countries evaluated on the top five principles for EBM; and Iceland listed among the top nine. Norway and Iceland were listed among the top four for the six indicators developed to evaluate successful EBM.

A significant difference is found with regard to how MAT is managed. The marine angling tourist businesses in Iceland must adhere to regulations written for the commercial fleet. All fish the tourists catch must be delivered to the fish factory and weighed in against the quota regularly purchased for the boats used in MAT. Catch and release is forbidden by law so unknown catch and release mortality is not an issue. As a result, Iceland has full control on all the statistics related to MAT. Further, Iceland offers no facilities for tourists to fillet and freeze the fish they catch, eliminating fish waste from this activity also. This tourist product was offered in 2006, and the resulting waste led to the conclusion that filleting/freezing would not be part of the tourist experience in Iceland (Solstrand 2013; Solstrand and Gressnes 2014; Solstrand 2014). Norway, in effect, does not have a definitive management strategy for MAT, and must rely on scientific studies that attempt to estimate total seasonal catch. There is no 
official registry for MAT businesses and/or the number of boats in use, no monitoring of how many marine angling tourists are fishing each season, or the mortality from catch and release fishing. As a result, a "black hole" of knowledge exists with regard to MAT statistics, introducing significant doubt as to whether the fjord stocks are being managed sustainably or not. In addition, each resident north from $62^{\circ} \mathrm{N}$ is allowed to land up to two tonnes of cod per calendar year under the category of recreational fisheries. South of $62^{\circ} \mathrm{N}$, the total allowable catch of cod for recreational fishers is one tonne. Total catch by recreational fishers is also unmonitored ${ }^{c}$.

The following example illustrates one of the ways the differences in natural resource management affects tourism management. World-record sized halibuts caught using only a rod and reel have been caught by marine angling tourists in Northern Norway in years 2009 (210 kg or $463 \mathrm{lbs}$ ) and 2011 (245 kg or $540 \mathrm{lbs}$ - beating the world record set in Iceland in 2010 by $25 \mathrm{~kg}$ ), but halibuts up to $175 \mathrm{~kg}$ are caught regularly each fishing season. Photos of these enormous fish are used in marketing Iceland and Norway as MAT destinations, tempting sport fishers with the fishing experience of a lifetime. Although Atlantic halibut is the most sought after trophy, it is listed as endangered on the IUCN 2013 red list $^{\mathrm{d}}$. As a result of Iceland's control on stock statistics, a fishing ban was enacted for Atlantic halibut December 2011 due to stock decline. If a halibut is caught and remains viable, it must be released. This is the one exception to Iceland's law prohibiting catch and release. A halibut ban can seriously impact tourism interests, so controlling the stock such that these bans are not necessary is preferable for sustainable tourism development.

Following the presentation of methodology, a new interdisciplinary theoretical model is introduced to analyse institutional function of an SES. This model was developed using, as background, Scott's institutional theory $(1995,2008,2014)^{\mathrm{e}}$, and modifications of Scott's theory of institutions for fisheries management following Jentoft (2004) and Johnsen and Eliasen (2011). In the results section, empirical natural resources data reflecting the differing management strategies from Iceland and Norway are presented. Using the theoretical model as a tool, and the empirical data on total seasonal catch, the discussion section presents a detailed institutional analysis to answer the following research question: From an institutional perspective, how is governance influenced by institutional structure, conditions, and inter-dynamics? This article builds upon Berkes' (2010) call for a reconceptualization of 'natural resources' and 'management' - and demonstrates how such an analysis can be utilized to meet the challenges faced in governing complex SESs such as consumptive wildlife tourism, where resource use and conservation come into conflict with tourism development.

\section{Methodology}

For this article, qualitative data was collected from multiple sources, effectuating crossvalidation, and enabling a more comprehensive, holistic analysis of MAT (Denzin 1978; Jick 1979; Yin 2009, p. 114; Decrop 1999; Denzin and Lincoln 1994). The collection of qualitative data followed Yin's six sources of evidence (Yin 2009, p. 101-112), i.e. detailed direct field observations; open-ended focused interviews with stakeholders at several operational levels (tourists, camp owners/daily leaders, commercial fishers, and government officials - in total 86 interviews); participant observations (where the author participated as a marine angling tourist); collection and analysis of formal 
documentation such as newspaper and web-based articles at the community and national levels, reports and email correspondence; archival data including government laws, regulations, statistics and maps; and photography. A detailed description of these six sources of evidence is found in Solstrand (2013).

\section{Multiple case study and case study unit of analysis}

A multiple-case study analysis was the selected research method based on Yin's Case Study Research Design and Methods (Yin 2009), with MAT as the unit of analysis. Two cases (Iceland and Norway) provided enough material for identifying a variety of similarities and contrasts. Yin (2009) provides the main methodological structure for this research project methodology following Yin's technical definitions of the case study method, and case study design.

Both the multiple case study approach and multiple data sources allowed the application of triangulation (Decrop 1999; Denzin 1978; Jick 1979; Oppermann 2000). The effectiveness of triangulation rests on the premise that the weaknesses or bias in each single source will be compensated by the counter-balancing strengths and perspectives of other sources (Oppermann 2000). It is assumed that multiple and independent sources do not share the same weaknesses or potential for bias (e.g. Rohner 1977; Johnson 1999). When all data is compiled, the general idea is that there will be convergence. However, another distinct advantage of triangulation is that if there is divergence in the data, it is more easily identified. Or in other words, the outliers emerge - equally important in the overall analysis.

The individuals within the unit of analysis (MAT) were the marine angling tourists themselves, and the fish camp owners/daily leaders. The organizations that were included in the study were fish camps that provided a specific type of accommodation for marine angling tourists. The accommodations were defined as proper fishing camps whose main tourist product offering was marine angling. Accommodations at these camps consisted of several cabins for rental, each offering four to eight beds. Rental of accommodations included the use of a boat for the duration of the holiday, with up to four tourists per boat. In some cases, houses or apartments with several beds rather than individual cabins were the accommodation but the businesses otherwise operated in a similar fashion. For each of the fishing camps included in this study in Norway, filleting and freezing facilities were available for the tourists. Private homes that rented out one or two rooms, and which offered one or two boats for use were not included in this study. Holiday facilities that had marine angling as one of many product offerings for tourists were also not included in this study. In Iceland, these same defining criteria were used with the exception that in Iceland, filleting/freezing is not part of the product offering for MAT.

\section{Field area}

The field area for this article included the Western Fjords of Iceland and the fjords of the three northern-most counties of Norway - Nordland, Troms and Finnmark (Figures 1 and 2).

\section{Field work}

Fieldwork in Iceland was conducted in September 2010 and in June 2011. There are only three companies operating fishing camps similar to those in Norway, and these 


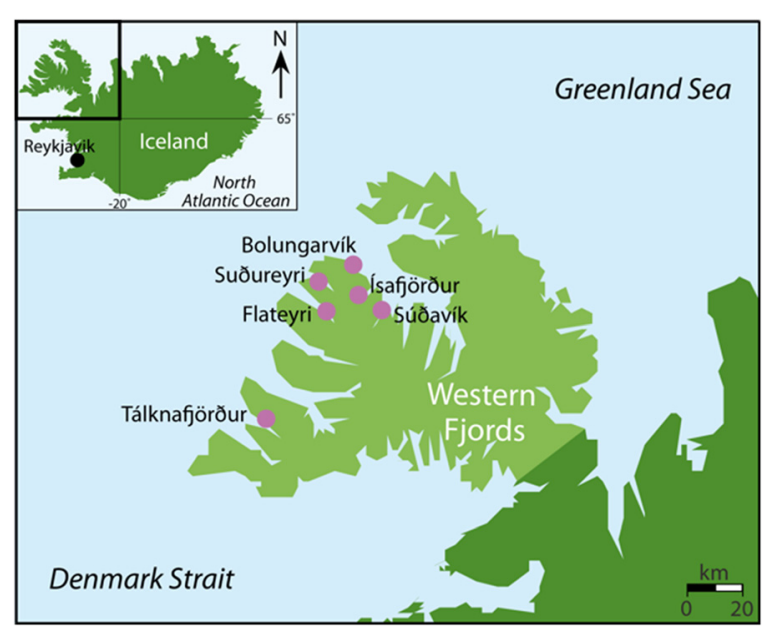

Figure 1 Field sites in Iceland. Five small communities are the sites of fishing camps in the Western Fjords. Ísafjörður is not the site of a fishing camp, but is marked as a reference point.

camps are located in the Western Fjords, in the small fishing villages of Súđavik, Suđureyri, Flateyri, Bolungarvík and Tálknafjörđur (Figure 1). All camps but one were visited twice, for a total of 9 camp visits. Fieldwork involved interviewing government officials ( 6 in total), making direct field observations at each fishing camp, open-ended focused interviews with the camp owners/daily leaders (3 in total), photographing the facilities, and collecting formal and archival documentation. No interviews with tourists were conducted in Iceland due to language barriers.

Fieldwork in Northern Norway (Figure 2) was conducted from April-August 2009 and April-August 2010, by driving in geographic order from North Cape to Northern

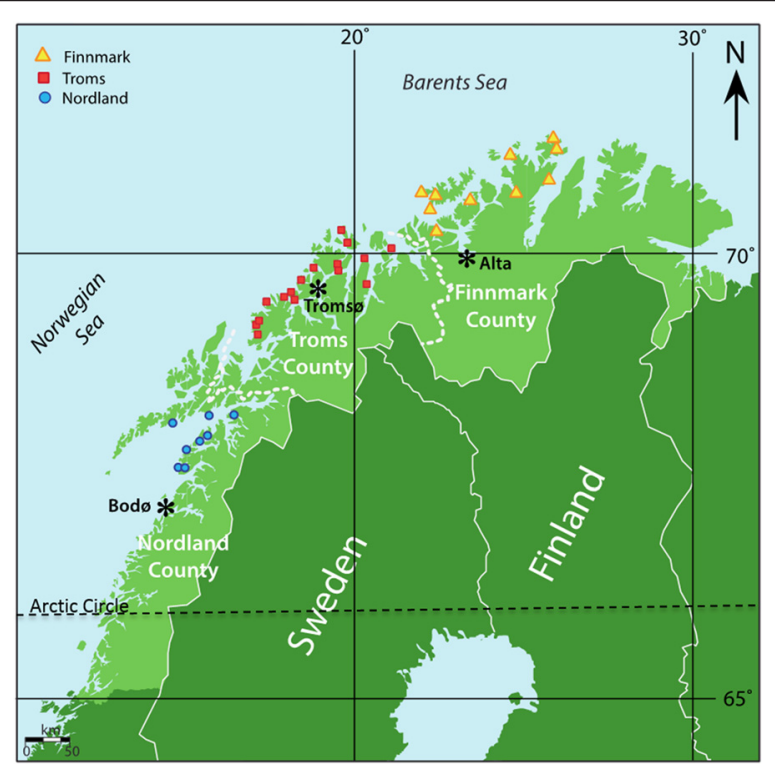

Figure 2 Field sites in Northern Norway. The field area for this project lies between $67^{\circ}$ and $71^{\circ} \mathrm{N}$, above the Arctic Circle, along a coastline of islands, fjords, and quaint coastal communities connected by car ferries and bridges. Fishing depths can vary from 15 to 200 meters even inside the fjords. 34 field sites are marked in the three northern-most counties of Norway — Nordland, Troms and Finnmark. Regionally, this area is known as Northern Norway. 
Nordland. Data collection included all above listed qualitative methods for Iceland, as well as participant observations, where the researcher personally experienced going out on a boat with the tourists, fishing as a tourist, and filleting the fish as a tourist. There were 20 camp visits in 2009, and 25 camp visits in 2010. 34 different camps were visited that met the qualifications for data collection criteria (marked on Figure 2). 77 open-ended interviews were conducted in Northern Norway, with stakeholders at several operational levels. This included 44 interviews with fish camp owners (12 female); 6 daily leaders; 12 interviews with 32 tourists ( 1 female); 7 fishing guides; 3 charter fishing operators; 2 tour operators; 1 professional fisher; and 2 government officials. Inclusion criteria for the tourists who gave interviews were that they were on holiday as a marine angling tourist; their ability to communicate in Norwegian, Swedish or English; and willingness to be interviewed. The fish camp owners and daily leaders interviewed, in all but one case, were local residents; and in some cases were either active or former small-scale fishers. As local residents, they were able to speak of their connections to the community and other local residents, and their experiences as owners of a MAT business in these communities. Interviews with local residents who were not fish camp owners or daily leaders were not conducted because this was outside the case study unit of analysis and the scope of the project design.

\section{Analysis of the data}

The objective of the interviews was to capture the essence of the experiences related to MAT. These experiences were then triangulated with the other five sources of evidence. The methodology for Interpretative Phenomenological Analysis (IPA) was chosen (Smith et al. 2009), but used as a basic guideline only, as the obstacles confronted when conducting cross-cultural (cross-lingual) interviews made following a strict procedure for interpretative analysis too difficult. If another type of methodology had been applied to the interview data, other types of analyses and certainly other conclusions could have been derived. This demonstrates a part of the inherently subjective nature of interview data.

The interview questions were open and general, and took the form of the following: Could you tell me about your experiences as a camp owner? Could you tell me about how you came to be a camp owner? Could you tell me about your best experiences as a tourist in Norway? Could you tell me about your worst experiences...? These types of questions usually opened the interview up such that a myriad of interesting stories and experiences emerged. Direct questions on the $15 \mathrm{~kg}$ export quota were most often met with an initial reaction of defensiveness and/or suspicion. Learning about how the export quota was affecting the tourist experience and the business operations became a significant embedded unit of analysis in the interview data. Often, tourists would redirect blame to other nationalities, and camp owners to other camps. Selected quotes were chosen to capture what were perceived to be relevant statements that were explanatory and reflective of experience. However, interview analyses and interpretations, in general, are a potential source of bias in qualitative research, and one of the reasons why triangulation was used.

For interviews conducted in English, in which the interviewees' mother tongue was not English, more simple vocabulary was used, which might have limited full descriptions of experiences to some degree. However, in all interviews, emergent patterns and 
themes within experiences could be identified. For example, in one interview, a Russian tourist explained: "fishing good, fishing very good, much big fish. I like. Camp good but Germans I no like. They freeze small fish. I no like." Although the English is broken, the experience is understandable.

In another example, a daily leader who used very simple English stated: "What we do with tourists who take much fish? We call and report." Here, this statement was referring to calling the border control to alert them of the license plate number of a vehicle coming across the border with excess fish fillet. It is simple language, but the meaning is understood. As a follow-up, it was confirmed with the Customs officials who were interviewed that indeed, several seizures were the direct result of tip-offs from the camps.

When comparing the number of interviews in Norway with Iceland, a few things must be noted. Several tourists interviewed in Norway had also been to Iceland, and could comment on a comparison of their marine angling experiences in both countries. The fieldwork in Iceland revealed that changes to the laws and regulations were happening both regularly, and recently. This meant it was possible to interview government officials who were directly involved in making these regulatory changes. It was also possible to talk to one official responsible for field visits to the fishing camps. No official was identified in Norway who could or would serve as a spokesperson for why the regulations for MAT are as they are. Nor could a person be identified to speak on the decision-making processes that led to the $15 \mathrm{~kg}$ export quota in 2006.

\section{Theoretical framework}

The theoretical framework begins with MAT as a complex socio-ecological system (SES) (Berkes et al. 2003; Berkes and Folke 1998; Ostrom 2009; Solstrand 2013; Solstrand 2014; Solstrand and Gressnes 2014; Berkes 2011). SESs can be defined as integrated complex systems, consisting of nested social (human) and ecological (biophysical) subsystems, integrated by two-way feedbacks through institutions of governance. Human-ecosystem interactions are a primary and highly complex component of MAT, coupled, and co-evolutionary (Berkes 2011; Berkes and Folke 1998; Berkes 2010). The interdependent living resource management and tourism management dynamics are multi-sectoral, with adaptations to change occurring along unpredictable pathways (Berkes 2010; Levin 2006; Berkes et al. 2003).

MAT as an institution can be seen as nested within the overarching institution of CPRs (Ostrom 1990; McCay and Acheson (1987); Jentoft 2004; Scott 2014). Ostrom's research on governance within common pool resource (CPR) institutions identifies conflict resolution as one of the critical institutional design principles for longenduring CPR institutions (Ostrom 1990, p. 90), in support of conflict research within tourism. Research in fisheries governance has similarly shown that resolving and mitigating conflicts between resource use and conservation efforts requires the creation of an effective, adaptive interactive governance strategy, in order to find balance between these two competing interests (Pascual-Fernandez et al. 2005; Jentoft et al. 2010).

Institutions are linked to each other and form networks that are themselves institutions. None are self-sufficient, in that their viability is dependent upon the type of relations established within the larger systems of which they are a part; therefore institutions must 
be analysed as "semi-open" systems that receive input from external sources, e.g. from other institutions (Pascual-Fernandez et al. 2005; Scott and Davis 2014). Institutions cannot remain static, isolated, or ignorant of change. Mechanisms must be in place for institutions to remain flexible and learn (Jentoft et al. 2010), especially with regard to emergent conflicts, with the implicit understanding that change is inevitable, and that adaptation is necessary for maintaining balance.

A modified version of Scott's institutional theoretical construct of three pillars of institutional order: regulative, normative and cultural-cognitive, form the underlying theoretical basis for creation of a model used in this article (Figure 3). Jentoft (2004) applies Scott's three institutional pillars to fisheries governance, arguing that the institutional framework for fisheries management must capture the intricacies of social and cultural processes of change that are essential to making fisheries more sustainable. In Jentoft's argument, the cultural aspect is not only assigned to the cognitive pillar of the

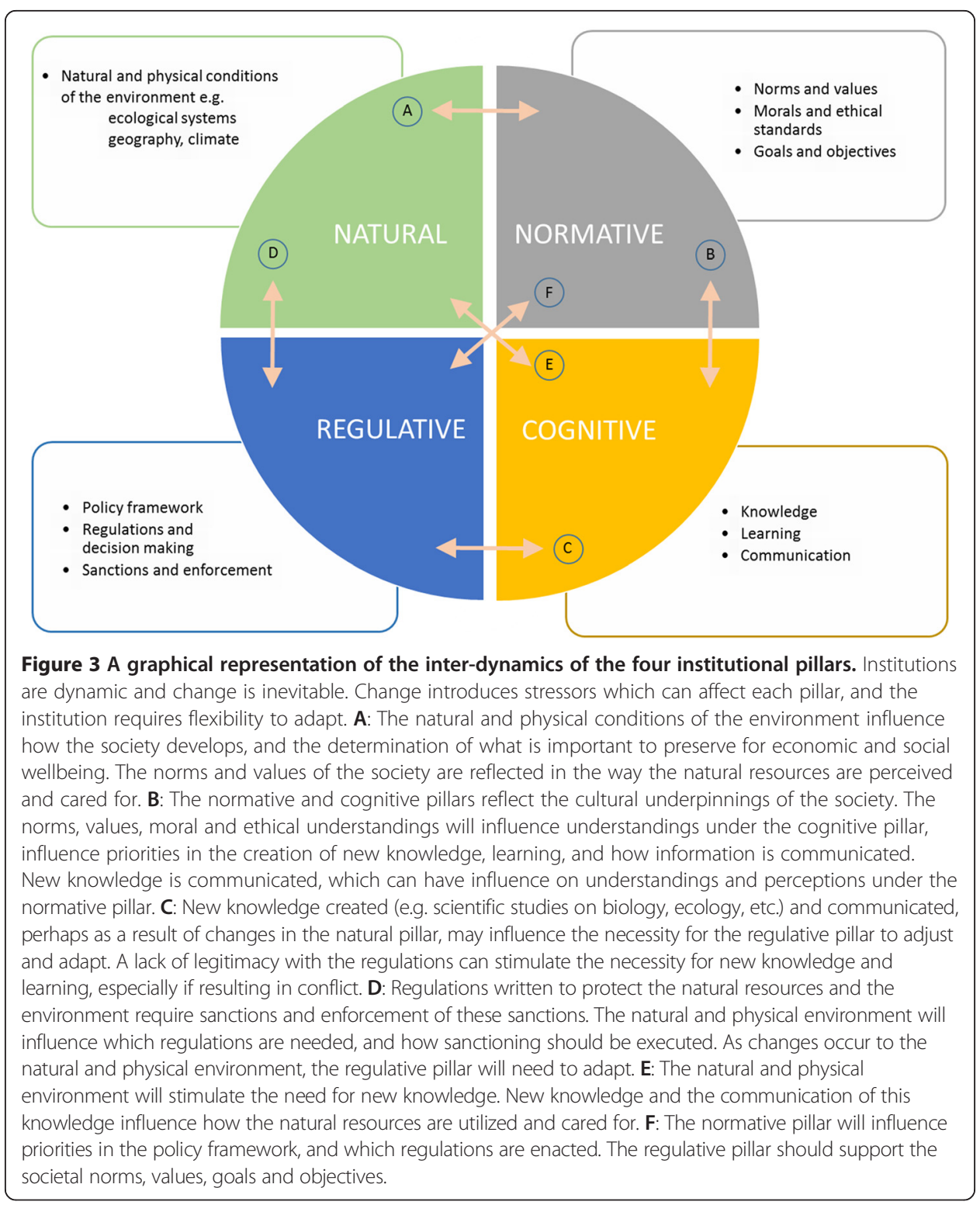


institution, but is a crucial component of both the normative and cognitive elements (Figure 3B). Jentoft stresses that communities play an essential role - both in fisheries management, and as hosts for tourists - and that the community must therefore be taken into consideration as a key stakeholder. Jentoft asserts that institutions for governance in fisheries must be constructed to allow for institutional learning, and must work from the bottom up as well as from the top down. Co-management that includes communities must be part of the institutional design, adhering to democratic principles of accountability and transparency, with sensitivity, which permits response to all affected interests (Jentoft 2000, Jentoft 2011; Jentoft et al. 2010; Jentoft 2004; Jentoft and Mikalsen 2014).

Johnsen and Eliasen (2011) examine the discard problem in fisheries management, adding a fourth institutional pillar titled the 'natural' pillar. Discards are the portions of fish catches that are thrown back into the sea. Discarding is a problem when the organisms returned to the sea are dead or mortally wounded, and represents biomass removal not taken into account in stock estimates (Johnsen and Eliasen 2011). The natural conditions as a fourth pillar is consistent with emerging research in fisheries, and the recognition that the social and ecological aspects of the management of fisheries can be considered as an integrated socio-ecological system (SES) (Berkes 2010, 2011; Ommer et al. 2011). The natural pillar holds the conditions of the natural environment - the biology, ecology, geology, geography and ecosystem functioning within the natural environment (Johnsen and Eliasen 2011) - which is part of the institution - not separate from it. The regulative pillar is influenced by the natural and physical conditions of the environment (Figure 3D) with rule-setting and monitoring designed for protection and sustainability. Non-compliance acts as a stressor to the system. If regulations and sanctions are not effective to control noncompliance, this will impact the sustainability under the natural pillar and will challenge regulative legitimacy under the normative pillar (Figure 3A, D, F). Non-compliance has the power to seriously unbalance the entire system. It cannot necessarily be eliminated from the institutional system, but can be mitigated depending on how the institution responds.

The normative pillar holds the evaluative and obligatory dimension of social life (Scott 2014). This pillar holds the norms, values, ethics, and morals - guided by the unwritten rules and understandings shared by society members (Briassoulis 2002; Folke 2007; Levin 2006; McCay and Acheson (1987); Ostrom 1990; Ostrom et al. 1999). Cultural underpinnings are applied under the normative pillar, consistent with the argument by Jentoft (2004) that norms specify how things should be done (e.g. the measure of appropriateness), according to the cultural framework of the society, providing legitimacy for how values are applied. Values in this context are held values, not assigned values (such as economic worth), and refer to the expressed relative importance or worth of an object to an individual or group in a given context (Brown 1984, p. 233). Through the normative pillar, the goals and objectives of the system are defined, as well as the expected roles that actors should play stemming from the shared cultural understanding. As a result, there is societal agreement and pressure to conform to the rules. Compliance here means behaviour of the individual reflects the norms and values held by the society, not self-interests. Therefore, within the society, noncompliance results in social judgement, shame, or disgrace (Scott 2014). However, this does not apply to the tourists who sit outside this cultural context. 
Cognition, by definition ${ }^{\mathrm{f}}$, is the mental action or process of acquiring knowledge and understanding through, for example, thought, and experiences. Within the cognitive pillar rests the deeper cultural understanding (through knowledge and learning), forming the foundation upon which the regulations and norms rest (Figure B, C). New knowledge is generated, e.g. scientific studies to understand biology, and ecology. Regulations are created, driven by society's "of course this is the way we do things" understanding. Legitimacy is measured essentially by what makes sense. However, in the case of tourism - tourists are not a part of this shared cultural understanding of what makes sense. What makes sense to the tourists has more to do with maximizing the tourist experience. They participate within, and influence the institution of MAT, but actually sit outside the normative and cognitive pillars.

Change is a given, and an institution is a dynamic system that is continually subject to stressors as a result of change. Forces (including conflicts), act from within and external to the system. The system must be flexible enough to adapt in order to minimize disruption from such stressors (Kooiman et al. 2005; Ostrom 1990; Scott 2014). In a stable system, no one single pillar functions alone, nor does any single pillar dominate. When the system is in balance, the capacity to adapt is high, and the chances for sustainability are far greater. When the system moves out of balance, it means that stressors are exerting force on one or more pillars, and that adaptation to re-establish balance becomes necessary (Strange and Sine 2002).

\section{Monitoring the fish as a resource - empirical examples from Iceland and Norway}

The following is a presentation of empirical data resulting from the differences in the management of MAT in Iceland and Norway. Applying the theoretical model, the Discussion section will discuss how this empirical data affects institutional functioning and sustainability.

Iceland

Known statistics in the Iceland system are used to calculate a figure that can be used to evaluate Norwegian estimates. In Table 1 , the average $\mathrm{kg} /$ boat/day is calculated for MAT in Iceland, by starting with published figures for total seasonal catch (in tonnes), the number of boats, and using a realistic low and optimistic high for the number of fishing days (calculations moving from right to left). Total seasonal catch $(\mathrm{kg}) \div$ fishing days $\div$ boats $=\mathrm{kg} /$ boat $/$ day. Over a four-year period, the total seasonal catch has been fairly consistent with a calculated average daily catch of 48-61 kg/boat/day (Table 1). Such a statistic remains independent of the number of marine angling tourists doing the fishing - a figure that is not available in Norway.

\section{Norway}

"At present, there are no precise and unbiased annual statistics available for total recreational fishing effort along the coast of Norway or on how much and which species are caught... Hence, there is a need for more and better information on the coastal zone to mitigate conflicts among stakeholders and to ensure sustainable fisheries" (Vølstad et al. (2011b), p. 1786). 
Table 1 The average $\mathrm{kg} / \mathrm{boat} / \mathrm{day}$ is calculated from known statistics in Iceland: the total seasonal catch and the number of boats, for years 2010-2013

\begin{tabular}{|c|c|c|c|c|c|}
\hline \multicolumn{6}{|c|}{$\leftarrow$ calculations move from right to left } \\
\hline & Season & Average kg/boat/day ${ }^{(a)}$ & $\begin{array}{l}\text { Number of } \\
\text { boats }\end{array}$ & $\begin{array}{l}\text { Number of fishing } \\
\text { days (low/high) }\end{array}$ & $\begin{array}{l}\text { Total seasonal } \\
\text { catch (tonnes) }\end{array}$ \\
\hline \multirow[t]{5}{*}{ Iceland } & 2010 & 53 to $66 \mathrm{~kg} /$ boat $/$ day & $47^{(\mathrm{b})}$ & $80 / 100^{(a)}$ & $247^{(b)}$ \\
\hline & 2011 & 48 to $60 \mathrm{~kg} / \mathrm{boat} /$ day & $48^{(c)}$ & $80 / 100^{(a)}$ & $232^{(c)}$ \\
\hline & 2012 & 49 to $62 \mathrm{~kg} / \mathrm{boat} /$ day & $49^{(d)}$ & $80 / 100^{(a)}$ & $242^{(d)}$ \\
\hline & 2013 & 43 to 55 kg/boat/day & $48^{(\mathrm{e})}$ & $79 / 100^{(f)}$ & $207^{(\mathrm{e})}$ \\
\hline & Average & 48 to $61 \mathrm{~kg} / \mathrm{boat} / \mathrm{day}$ & 48 & & 232 \\
\hline
\end{tabular}

(a) Government regulations reserve quota for the months of May, June, July and August (123 fishing days). Based on the interviews conducted, 80 reflects a realistic figure for a typical season. 100 is an optimistic high, with only 23 days of the season lost due to bad weather and wind conditions. In Iceland, not all boats are fishing all days due to a varying number of guests, and weather is always a factor.

(b) Fiskistofa (2010, pg. 10) modified after an interview with Fiskistofa October 2011. 227 tonnes cod (92\%); 14 tonnes wolffish (6\%); 3 tonnes haddock; 2 tonnes saithe; 1 tonne halibut.

${ }^{(c)}$ Fiskistofa (2011): 219 tonnes cod (94\%); 10 tonnes wolffish (4\%); 1 tonne each saithe and haddock.

(d) Fiskistofa (2012): 228 tonnes cod (95\%); 10 tonnes wolffish (4\%); 1\% other.

${ }^{(e)}$ Fiskistofa (2013): 182 tonnes cod (88\%); 19 tonnes wolffish (9\%); 3\% other - The drop in total tonnage was attributed mostly to weather, but there was also a noted change in the number of guests and group composition (i.e. more families).

${ }^{(f)}$ Personal communication with fish camp owner, 19 March 2014, confirmed 79 fishing days for 2013. For this camp, average seasonal take is from 120-160 tonnes. For 2013, the total catch was $150+$ tonnes. For 21 boats, the average was approx. $90 \mathrm{~kg} / \mathrm{boat} / \mathrm{day}$. The average group size was 3.8 fishers.

To compensate for the lack of official statistics, three major studies have been conducted over a ten-year period in an attempt to estimate total seasonal catch for MAT in Norway (Table 2). These studies have produced widely differing results depending on how the question was approached, and how the calculations were done. Although field data for the current project shows that MAT is increasing in Northern Norway, the estimates for how much fish is actually being harvested have decreased significantly with each successive estimate of total seasonal catch. The only number one can claim to know with any certainty might be the number of boats. Based on Vølstad et al. (2011b), the total number of boats used for MAT is calculated to be 2,393 for all of Norway in 2009; and Borch et al.'s (2011) figure of 907 boats is used for Northern Norway as of 2009. Vølstad et al. (2011b) use a figure of 445 official marine fish tourism businesses in Norway as of 2009, while the study by Hallenstvedt and Wulff (2001)

Table 2 Seasonal catch estimates from MAT in Norway - studies done over a ten-year period

\begin{tabular}{|c|c|c|c|c|}
\hline Year & Authors (Date of report) Institutions & $\begin{array}{l}\text { Estimated } \\
\text { seasonal catch }\end{array}$ & $\begin{array}{l}\text { All of } \\
\text { Norway }\end{array}$ & $\begin{array}{l}\text { Northern } \\
\text { Norway }\end{array}$ \\
\hline \multirow[t]{2}{*}{2001} & Hallenstvedt and Wulff (2001) & \multirow{2}{*}{$\begin{array}{l}13,400 \text { tonnes with a } \\
\text { range of } 12,000-15,000 \\
\text { tonnes per year }\end{array}$} & \multirow{3}{*}{$\begin{array}{l}\sim 10,000 \text { boats } \\
939 \text { businesses }\end{array}$} & \\
\hline & $\begin{array}{l}\text { Norwegian College of Fishery Science, } \\
\text { University of Troms } \varnothing\end{array}$ & & & \\
\hline 2003 & $\begin{array}{l}\text { Cap \& Ernst (2003) Int'l consulting firm } \\
\text { (now known as Capgemini Consulting) }\end{array}$ & $\begin{array}{l}6,000-9,000 \text { tonnes } \\
\text { per year }\end{array}$ & & \\
\hline 2011 & $\begin{array}{l}\text { Vølstad et al. (2011 b); Vølstad et al. (2011a) - } \\
\text { Institute of Marine Research under Ministry } \\
\text { of Fisheries and Coastal Affairs, Bergen }\end{array}$ & 3,335 tonnes per year ${ }^{(b)}$ & $\begin{array}{l}\text { 2,393 boats } \\
445 \text { businesses }\end{array}$ & 907 boats $^{(c)}$ \\
\hline
\end{tabular}

(a) For 2001-2002, based on all of Norway, with an average per fisher of $60 \mathrm{~kg}$ per vehicle. An estimate of approximately 10,000 boats of varying sizes was used - available to tourists staying in organized accommodations.

(b) For 2009, based on all of Norway with an error margin of 17\%; 1,613 tonnes cod (22\% error margin). For Northern Norway, 2,298 tonnes annually. Calculation based on catch diaries where only the harvest (fish kept) was recorded. This figure does not include fish mortality from catch and release.

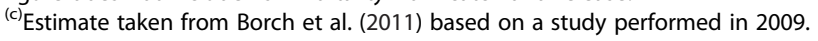


estimates that 939 businesses were in operation in 2001. The estimates of total seasonal catch from these three reports are compared in Table 2.

Catch-and-release, as a fishing practice, has significant bearing on fish stock management from a biological, ecological, and socio-cultural perspective (see for ex. Arlinghaus 2007; Ferter et al. 2013; Ferter et al. 2015; Arlinghaus et al. 2007). Implementation of best practice release guidelines are recommended in order to minimize the negative impacts of C\&R (Ferter et al. 2015). No reliable estimates for catch-and-release mortality are available for MAT activities in Norway. With the estimate of 3,335 tonnes as a total seasonal catch for all of Norway (which does not include catch and release mortality), Vølstad et al. (2011b); Vølstad et al. (2011a) conclude that the tourist catch of coastal cod is insignificant in comparison to commercial scale and recreational fishing by Norwegian residents. Many government statistics controlling commercial-scale fisheries management in Norway distinguish between areas north and south of $62^{\circ} \mathrm{N}$. The overall sizes of the fish and composition of species caught in Northern Norway increases the $\mathrm{kg} / \mathrm{boat} /$ day statistic substantially, in comparison to southern Norway, which also has bearing on attempting to find an estimate for the entire country.

Estimates of total seasonal catch listed in Table 2 are vastly different. Using these estimates from Table 2, with the known data from Iceland presented in Table 1 for comparison, Table 3 presents another way to estimate total seasonal catch in Norway. Working the calculations from left to right in Table 3, the starting point is the average $\mathrm{kg} / \mathrm{boat} /$ day found in Table 1. Further, the figures used for the number of boats for MAT are only estimates. With an increase in the number of boats, the figure for total seasonal catch rises significantly. These estimates of total seasonal catch would be in addition to tourist fishing activities occurring along the coastline outside of fishing camps, unknown landings from illegal fish smuggling activities, and the recreational fishing activities by Norwegian citizens. These activities, which collectively represent a significant number of additional boats also involved in the extraction of fish resources, are also unmonitored and have no estimates.

Table 3 Total estimated seasonal catch in Norway calculated by using a range of figures for $\mathrm{kg} / \mathrm{boat} / \mathrm{day}$ taken from Table 1

\begin{tabular}{|c|c|c|c|c|}
\hline & \multicolumn{4}{|c|}{ Estimate of seasonal catch } \\
\hline & \multicolumn{2}{|c|}{ All of Norway (tonnes) ${ }^{(a)}$} & \multicolumn{2}{|c|}{ Northern Norway (tonnes) ${ }^{(\mathbf{b})}$} \\
\hline & Fishing days & & Fishing days & \\
\hline calculations $\rightarrow$ & $\operatorname{low}^{(c)}$ & high $^{(\mathrm{d})}$ & $\operatorname{low}^{(c)}$ & high $^{(d)}$ \\
\hline 61 kg/boat/day ${ }^{(e)}$ & 22334 & 31092 & 8465 & 11785 \\
\hline 48 kg/boat/day ${ }^{(e)}$ & 17574 & 24466 & 6661 & 9273 \\
\hline 30 kg/boat/day & 10984 & 15291 & 4163 & 5796 \\
\hline 20 kg/boat/day & 7323 & 10194 & 2775 & 3864 \\
\hline 10 kg/boat/day & 3661 & 5097 & 1388 & 1932 \\
\hline 8 kg/boat/day & 2929 & 4078 & 1110 & 1546 \\
\hline
\end{tabular}

${ }^{(a)}$ Based on the reported figures for number of boats in Vølstad et al. (2011b) - 2,393 boats for all of Norway.

(b) Based on the reported figures for number of boats in Borch et al. (2011) - 907 boats for Northern Norway.

(c) Based on a low estimate of 153 possible fishing days in peak season: $1 / 2$ April (15 days), May (31 days), June (30 days), July (31 days), August (31 days), and $1 / 2$ September (15 days). All camps visited reported full bookings for the season. Not even the newly established camps had vacancies.

${ }^{(d)}$ Based on a high estimate of 213 possible fishing days. Several camps in Northern Norway open in mid-March and run into mid-October.

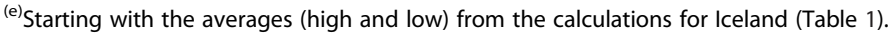


The direct field observations and interview data in Northern Norway in 2009 and 2010 documented that marine angling tourists (average of four per boat) were typically landing a full box of fish after a day on the sea - with an average estimated weight of between 50 to $70 \mathrm{~kg}$. Direct field observations also confirmed that camps were fully booked throughout the season, and all boats were in use. Average-sized cod are approximately $5-15 \mathrm{~kg}$, and the tourists were typically coming in with over six cod (>30 kg), one to four wolfish (3$7 \mathrm{~kg}$ each avg.), a few saith (2-4 kg each) and haddock (2-3 kg each) ${ }^{\mathrm{g}}$ and/or redfish. If a halibut was in the box, the total number of kilos rose considerably, as just one 1.5 meter halibut is approximately $50 \mathrm{~kg}$. It was very seldom fishers were coming into camp with no fish. If it was just the fish for dinner they were landing, then it was still up from $20 \mathrm{~kg}$ (e.g. 3-4 average sized cod) to feed the group (on average $25 \%$ of the fish is fillet). Using Table 3 as a reference, Vølstad et al.'s estimate would place between $8-10 \mathrm{~kg} / \mathrm{boat} /$ day for all of Norway (3,335 tonnes annually) and a little over $10 \mathrm{~kg} /$ boat/day for Northern Norway (2,298 tonnes annually).

\section{Discussion}

The inter-dynamics of the institutional pillars based on the differences in the management systems for MAT, and highlighting the data from the section Monitoring the fish as a resource - empirical examples from Iceland and Norway, are discussed in the following order: natural, regulative, normative, and cognitive.

\section{Natural pillar}

Elements under the natural pillar include but are not limited to, the geography, climate, ecosystem functioning, biology, and the integrity of the fish stocks. The figures in Table 1 and Table 2 are used for natural resource management of the fish stocks; however, the figures require legitimacy in order for the management to be effective.

Iceland

From a natural resource management perspective, there is no distinction made between fish caught commercially or fish caught by tourists. Catch and release is against Icelandic law, and filleting/freezing fillet is not a product offering as part of the tourist experience because the waste factor is significant (Solstrand 2013; Solstrand and Gressnes 2014; Solstrand 2014). With a full accounting of the catch statistics, the number of tourists and boats, Iceland maintains control on the fish stocks through strict control on monitoring. Though not shown, statistics are also available which track the individual activity of each boat for each day the boat is used. This allows for more localized statistics on the amount of fish extracted around each camp location. These official statistics continually create new knowledge (Figure 3E), and provide legitimacy to the efforts of natural resource management (Figure 3D).

However, from a tourism perspective, this strict control might come at a price for tourism development. Iceland lies between latitudes $63^{\circ}$ and $67^{\circ} \mathrm{N}$. It is a volcanic island of $103,000 \mathrm{~km}^{2}$ in the middle of the North Atlantic (Figure 4), often with challenging weather conditions. Transportation is a significant issue for MAT in the Western Fjords - it is an extremely remote location, even for Icelanders. As can be seen from Table 1, the number of boats has remained essentially constant over the last four years at approximately 48, shared by three companies. Harsh wind and weather conditions in 


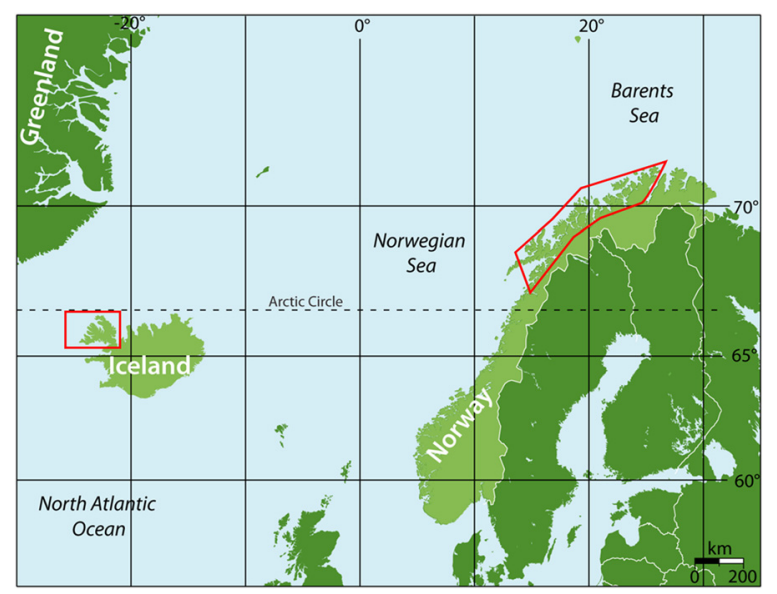

Figure 4 Geographic comparison of the Western Fjords and Northern Norway. Monitoring of marine fishing activities inside the fjords along Norway's $83,281 \mathrm{~km}$ coastline, and sanctioning violations of the $15 \mathrm{~kg}$ export quota are formidable governance challenges. Assisting in non-compliance by the tourists is the geographic accessibility to Norway's coastline by land vehicles from mainland Europe and Russia.

Iceland can prevent tourists from being able to go out on the boats for several days of their holiday (reflected in the number of fishing days in Table 1). In addition, tourists are not allowed to fillet their own fish, but must purchase fish if they want to take it home with them (Solstrand 2013). These factors may contribute to why no significant growth has been seen in MAT in Iceland for the last four years. It may be that Iceland would need to offer some incentives to tourists in order to compensate for the strict stock control, harsh weather and geography.

From a natural resource management point of view, the geography assists in controlling fish smuggling by the tourists. Marine angling tourists are flown to and from Iceland mostly as part of organized charter groups. The camp owners cooperate and coordinate transportation such that all tourists arrive and leave on the same days (approximately 90 tourists per week during peak season). This helps keep costs down for the tourists, especially if weather disturbs the transportation logistics. However, the geography also provides a natural deterrent to fish smuggling. It cannot be said with any certainty that smuggling does not occur in Iceland, but it was not a topic that came up in the interviews. For smuggling to occur, marine angling tourists would need to overcome some challenging obstacles: filleting and freezing facilities are not available in the camps; tourists would need to pay for additional weight on the return flight; and the tourists arrive and depart in large charter groups with all luggage (and extra luggage) clearly visible and monitored. For tourists who arrive on their own, perhaps by car ferry, smuggling might be somewhat easier, but the price of the holiday rises significantly, calling into question whether the amount of smuggled fish would actually produce a profit.

\section{Norway}

Including all the fjord formations and hundreds of islands, Norway has a total coastline of $83,281 \mathrm{~km}^{\mathrm{h}}$, more than twice the earth's circumference of 40,075 km (Figure 4). This geography plays a key role in the smuggling of fish by tourists. In 2006, Norway enacted a quota of $15 \mathrm{~kg}$ of fish or fish products that can be exported in a 24-hour 
period (addressed in more detail under the regulative pillar). The geography makes it possible for tourists to drive their own vehicles from mainland Europe and Russia (Figure 4). Theoretically, tourists can fish wherever they wish along the extensive coastline and extract as much fish as they like, without breaking Norwegian law, as long as they use only rod and reel, do not sell their catch, and do not export more than $15 \mathrm{~kg}$ in a 24 hour period. Unlike Iceland, if tourists' primary motivation includes taking illegal amounts of fish out of the country, the geography assists rather than hinders this non-compliance with Norwegian law. Sanctioning non-compliance can only be done at the border crossings, because as long as the tourists remain in Norway and do not sell their catch - although they may have acquired hundreds of kilos of fillet over the export quota during their stay - they have technically not broken Norwegian law until they have crossed over the border. Non-compliance creates conflict in the institutional system in Norway. The consequences of non-compliance from an institutional perspective are addressed under the regulative, normative and cognitive pillars.

The widely differing estimates provided in Table 2 raise the question of which estimate holds the greatest amount of legitimacy. The calculations in Table 3, in combination with field data and interviews would indicate that perhaps the most recent estimate may be too low. There is a serious risk in using estimates for natural resource management that are not accurate (Figure 3D). With regard to stock integrity, genetic studies suggest that the coastal cod living in the fjords may be genetically different from the open-sea Arctic cod stocks migrating from Lofoten to the Barents Sea (e.g. Fevolden and Pogson 1997; Pogson and Fevolden 2003). This would mean that the tourists are most likely fishing distinct populations of non-migrating, local stocks of cod residing in the fjords. For some fjords, increased temporal and spatial stressors from tourist fishing may increase stock vulnerability; however, without the availability of baseline statistics, there is no way to further evaluate this.

The 2013 report from the ICES Arctic Fisheries Working Group outlines a rebuilding plan for coastal cod, adopted by the Norwegian government in 2010, as the result of a drastic decline of coastal cod stock in recent years (ICES 2013). "The management regime employed is aiming for improved ecosystem monitoring in order to understand and possibly enhance the survival of coastal cod" (ICES 2013, p. 98) (Figure 3D). ICES considers their proposed plan to be provisionally consistent with the precautionary approach; however, the lack of monitoring statistics for such a significant portion of coastal cod mortality and landings from both tourist and recreational activities is not consistent with EBM or the precautionary approach. The latest estimate from Vølstad et al. (2011a, b) for the total seasonal catch for MAT quieted the debate on stricter regulations for coastal cod, which can seriously impact the natural pillar, generating a ripple effect to the normative, cognitive and regulative pillars (Figure 3A, D, E ) discussed below.

\section{Regulative pillar}

Regulations for MAT are nested within a fisheries institution of common pool resources in both Iceland and Norway. The laws that control CPR for both countries share congruent goals. Both laws state, first and foremost, that the wild living marine resources are a common pool resource; both laws state the priority to promote stable employment and regional development in the vulnerable coastal communities; and 
both laws state the importance of caring for the wild living resources in a sustainable manner with consideration given to future generations (Table 4).

Iceland

In Iceland, the regulations governing MAT are nested in the Fisheries Management Act, which was first signed into law in 1990. This Act establishes the Individual Transferable Quota (ITQ) system for Icelandic fisheries where quotas represent shares in the national Total Allowable Catch (TAC). In August 2006, the Fisheries Management Act was re-issued as Law nr. 116/2006, incorporating all changes made to the original Act of 1990. In 1996, the law on the treatment of exploitable marine stocks banned catchand-release fishing (Alpingi 1996). An exception to this law was passed in December 2011 (Alpingi 2011), due to the serious decline in the halibut population. If a halibut is caught and remains viable it must be released. Marine angling tourists are required by law in Iceland to use only a rod and reel, and the sale of catch is forbidden.

Iceland's regulatory system for MAT makes essentially no distinction between tourist businesses and commercial-scale fishers with regard to how the fish are handled as a resource, i.e. ITQ as a part of TAC. The fish camps own the boats, boats must be registered, and quota must be purchased for each boat engaged in tourist fishing. If the tourist boat registers no fishing activity, it loses its quota. The tourists must deliver their fish catch daily to the local fish factory for processing, and the amount of the fish is weighed in against the quota of the boat, which must be regularly replenished throughout the summer months by the camp owners. The tourists cannot use the boat if it does not hold a quota. Tourists are permitted to take fish home with them, but they must buy this fish separately.

The strict regulatory framework supports EBM (Figure 3D), and allows Iceland to demonstrate full transparency with regard to important catch statistics for MAT activities. The trade-off is that MAT businesses must adhere to regulations written for the commercial fleet. This is a significant source of conflict for tourist development, but in full agreement with the normative pillar (Figure 3F). Field research primarily identified that MAT conflicts originated from the regulative pillar - i.e. MAT businesses having to adjust to operate under the same strict regulations designed for the commercial fleet.

As a result, the government and the business owners have prioritized communication mechanisms in part through feed-back loops as a way to mitigate these conflicts. As discussed in detail in Solstrand (2013), from a regulative standpoint, multiple examples exist where the Icelandic government has prioritized conflict mitigation in the MAT

Table 4 Comparison - Fisheries Management Act of Iceland and the Marine Resources Act of Norway

\begin{tabular}{|c|c|c|}
\hline & Iceland & Norway \\
\hline & Fisheries Management Act & Marine Resources Act \\
\hline Common pool resource & $\begin{array}{l}\text { Fish stocks in Icelandic waters are } \\
\text { the common property of the } \\
\text { Icelandic nation }\end{array}$ & $\begin{array}{l}\text { The wild living marine resources belong to } \\
\text { Norwegian society as a whole }\end{array}$ \\
\hline $\begin{array}{l}\text { Employment and } \\
\text { regional development }\end{array}$ & $\begin{array}{l}\text { [To] ensure stable employment } \\
\text { and regional development }\end{array}$ & $\begin{array}{l}\text { [T]o promote employment and settlement in } \\
\text { coastal communities }\end{array}$ \\
\hline $\begin{array}{l}\text { Sustainability and } \\
\text { conservation of } \\
\text { fish stocks }\end{array}$ & $\begin{array}{l}\text { [T]o promote the conservation and } \\
\text { efficient utilization [of the fish stocks] }\end{array}$ & $\begin{array}{l}\text { T]o ensure sustainable and economically } \\
\text { profitable management of wild living marine } \\
\text { resources and genetic material derived from them }\end{array}$ \\
\hline
\end{tabular}


sector, through relatively rapid and consistent changes in regulations and laws. However, none of the changes in the regulative pillar create exemptions. The Icelandic regulative system for MAT is strict, but the government has demonstrated flexibility in mitigating conflict through interactive governance strategies that include interactions, institutional learning processes and adaptation (Figure 3C).

\section{Norway}

Unlike in Iceland, the MAT regulations are separate from those for the commercial fleet. The overarching law that governs wild living marine resources in Norway is the Marine Resources Act (Table 4) enacted 6 June 2008 (MFCA 2008). Another regulation enacted in 2006 (FKD 2006), controls how much fish foreign tourists can export. $\$ 2$. Export quota: It is not allowed to take out of the country more than $15 \mathrm{~kg}$ of fish or fish products per person, including processed products such as fish fillet, within a period of 24 hours ... In addition to this export quota, it is permitted to export one whole trophy fish, independent of weight. With violations over the allowed quota, the fish or fish products can be confiscated. Another regulation, enacted in January 2010, sets the minimum sizes for each species of fish, and requires that undersized fish be released. As in Iceland, tourists can only use a rod and reel, and the sale of catch is forbidden. The tourists, by law, are allowed to fish as much as they want; therefore, the $15 \mathrm{~kg}$ export quota can in no way be interpreted as a means to control fish mortality.

ICES (2013) reports that the commercial fleet tonnage of coastal cod for all of Norway in the last four years is as follows: 31,907 (2012); 28,594 (2011); 22,925 (2010) and 24,821 (2009). However, ICES cannot report statistically on coastal cod landings from tourist and recreational fisheries. "Recreational fisheries take an important fraction of the catches in some local areas, especially near the coastal cities and in some fjords where commercial fishing activity is low. There is no reporting system for the amount of Norwegian coastal cod (NCC) taken by recreational or tourist fishers in Norway." (ICES 2013, p. 90).

Based on estimates, the government of Norway has assigned a quota of 12.700 tonnes of coastal cod which includes all recreational and tourist fishing for the entire country. This figure includes all Norwegians who are fishing for their own personal use, as well as MAT fishing activities. As of 1 February 2013, recreational fishers north of $62^{\circ} \mathrm{N}$ can fish up to two tonnes of cod per calendar year under recreational fishing regulations $\mathrm{s}^{\mathrm{i}}$. Looking at Table 3, if $48 \mathrm{~kg} /$ boat/day or higher is used as an example of average catch for Norway, the numbers do not differ to any great degree from the figures for commercial catch. Figures for Northern Norway alone approach approximately half of the commercial landings for coastal cod for 2009 and 2010 (assuming the estimate for the number of boats is fairly accurate), without taking into consideration catch-and-release mortality, unmonitored fishing along the coastline, and recreational fishing by Norwegian residents. Therefore, it is not unreasonable to suspect that the reserved quota of 12.700 tonnes of coastal cod is too low. Reserving extra coastal cod quota for the recreational and tourist fishing sector, however, means there would be less available for the commercial fleet, so making a decision to increase the tourist and recreational quota would have economic consequences for the commercial fishers creating additional conflicts. 


\section{Normative pillar}

The normative pillar is driven by societal norms, values, morals and ethical understandings of responsibility - which are in many cases guided by the unwritten rules and cultural understandings shared by the society members. The priorities of the society are reflected in the regulative pillar (Figure 3F).

In the sport of fishing, the temptation to catch/take more is always present; but for societies that have their identities rooted in sea-fishing traditions going back for hundreds of years, those members who break written or unwritten rules are often subject to peer judgement (Figure 3A). Under the normative pillar, sanctioning through shame or disgrace comes in addition to any sanctions for non-compliance levied under the regulative pillar (Scott 2014).

Iceland's Fisheries Management Act and Norway's Marine Resources Act are rooted in the same socio-cultural values that respect and honour the fish as a CPR, the marine fishing heritage, and protection of the wild marine living resources for future generations (Figure 3F). This can be seen through the similarities in the stated goals listed in Table 4, the regulations that govern the commercial fishing fleets, and the country rankings produced by Pitcher et al.'s study (Pitcher et al. 2006; Pitcher et al. 2009; Ward et al. 2002).

Marine angling tourists, coming from other countries, may or may not share in the values held by the Icelanders and Norwegians with regard to the fish as a resource. The tourists are not part of the local community. To them, the fish is part of the experience they are paying for (Solstrand 2014), and the "voice" of the community creates no consequences for them. The sheer volume and sizes of fish that can be caught creates an enormous economic temptation, since Norwegian fish fillet can be sold in mainland Europe for a substantial profit (Solstrand 2013; 2014).

\section{Iceland}

Iceland's regulatory system - in combination with geography under the natural pillar in large part protects, and provides legitimacy to the norms, values and morals that underpin the normative pillar (Figure 3F).

As discussed under the regulative and natural pillars, the system in Iceland does not make it easy for tourists to exercise non-compliance, should they be so inclined. By choosing Iceland as a destination, tourists are essentially choosing compliance with Iceland's regulations. In essence, their behaviour does not challenge the normative pillar.

Iceland's values with regard to the fish became evident in a quote from one of the camp owners, after being asked why Iceland does not offer tourists the ability to fillet and freeze their own fish. In 2006, one company began to offer the tourists filleting as a tourist product, modelled after Norway:

"It was a complete mess. 90 guests filleting fish and they did not even know how to hold a knife. The fish would be so messed up, they ended up throwing half the fish away."

This one example had introduced a challenge to the normative pillar, and so it was no longer an option as a tourist product, even though it might make Iceland more attractive as a destination for MAT. 


\section{Norway}

Interview data, field observations, participant observations, and media reports all corroborate that the estimates in Table 2 do not provide legitimacy to the normative pillar, and this is resulting in institution-wide stress. The continual need for new estimates is driven, to a large degree, by reports of confiscations and conflict scenarios communicated through the media under the cognitive pillar.

As discussed under the above section on the natural pillar, because marine angling tourists might be tempted to take more fish home with them than is allowed by the $15 \mathrm{~kg}$ export regulation, a certain percentage of them do. Marine angling tourists (and also camp owners) can be driven primarily by self-interests rather than the collective interests of the host society, as described in Hardin's tragedy of the commons (Hardin 1968) (Solstrand 2013; Solstrand and Gressness 2014; Solstrand 2014). Conflict scenarios are rooted in both differing values and interests, and motivations to exceed the $15 \mathrm{~kg}$ export quota are not rooted in the protection of the fish stocks for future generations, but in personal gain.

Whereas commercial fishers who break the law would most likely have to answer to their peers, tourists who choose non-compliance do not experience any form of societal judgement as a sanction, or a feeling of shame. If caught (and under 10\% of illegal exports of fish fillet are confiscated according to interviews with Customs officials), the tourists receive a fine and the fish fillet is thrown away. Nevertheless, individual confiscations at the borders, which can total hundreds of kilos of fillet over what is permitted by law, are consistently and sensationally reported in the local media each fishing season (Solstrand 2013; Solstrand and Gressnes 2014), impacting local communities' perceptions of the tourists and the camp owners. If the tourists who are fined so wish, there is nothing stopping them from returning to Norway to try again. While foreign tourists typically do not read Norwegian newspapers, articles on non-compliance by tourists, as essentially the only form of communication in MAT, are a continual normative stressor to the residents of the local communities (Figure 3B).

Media reports of non-compliance from Northern Norway receive national attention, and have in part prompted the continued attempts to estimate total seasonal catch. The question of how much the tourists are actually impacting the local fjord stocks is an ongoing question with no legitimate answer (Figure 3E). Customs authorities have consistently reported that the confiscations represent just the tip of the iceberg, and that smuggling of fish fillet has approached the level of organized crime (Solstrand 2014). The estimates listed in Table 2 do not take any of this illegal activity into account. The data for Vølstad et al. (2011b) estimate was taken from tourists who willingly filled out catch reports in fishing camps; however, the interviews with camp owners and customs officials conducted for this study suggest that some camps are in operation primarily to support large-scale smuggling. It is highly doubtful (though of course not completely unlikely) that any tourists from such camps would participate in such a study to estimate total catch. This type of large-scale smuggling is impacting the fish stocks in a way that is nearly impossible to estimate, given Norway's geography.

Non-compliance creates conflict and this conflict is not contained locally. The noncompliance issue has a ripple effect, reaching every aspect of the institutional structure and beyond into the local communities, commercial fisheries, and the nation. There is no legal mandate for fish camp owners to act as enforcers of the $15 \mathrm{~kg}$ export regulation, though the fish camps might be one of the few places where non-compliance 
could be effectively monitored. This challenges the moral and ethical responsibility of the camp owners with regard to this regulation (Figure 3F).

What has already been established is that tourists sit outside the values, morals, and ethics underpinning the normative pillar. However, many of the camp owners operating MAT businesses in Northern Norway are former professional fishers or have other ties to commercial-scale or small-scale fishing. Three quotes represent the range of thought on their moral and ethical responsibility.

Fish camp owner in Finnmark:

"Let's say you travel to Sweden to buy cheap alcohol and tobacco. Would you want the hotel manager to inspect your bags before leaving the hotel? Would you return to that hotel again? Is it the hotel manager's job to inspect your luggage?"

Fish camp owner in Troms:

"Media reports of tourists getting caught at the border are free publicity

for me, and this sends a good message to other tourists to come to my

camp because I have lots of fish!"

Fish camp owner in Troms:

"If we see tourists taking too much fillet, we report their license plate number to the Customs authorities at the borders."

The institutional structure does not reward those camp owners who choose to take the moral high ground to enforce the $15 \mathrm{~kg}$ export regulation. In fact, due to the highly competitive nature of MAT in Norway, camp owners can be penalized if they take a stand against non-compliance, in the form of reduced bookings. A camp owner that condones non-compliance cannot hide this business choice from other camp owners or the local community residents. It was revealed through interviews that the local residents watch the activities of the tourists, and whether or not the camp owner assists in controlling non-compliance. Camps that "allow" non-compliance by the tourists are actually not breaking Norwegian law, putting the burden of accountability on the tourists alone. Such a business choice sets up conflicts between these camp owners as hosts and the local residents.

Temptations for personal gain, supported by geography under the natural pillar, and in part by the limited ability to enforce sanctioning set up under the regulative pillar, have set in motion a series of conflicts rooted in divergent values and interests. The only mitigating effort that demonstrated any noticeable effect, was when the camp owner personally chose to legitimize the societal values, morals, and ethics that support the $15 \mathrm{~kg}$ export regulation by voluntarily enforcing Norwegian law.

\section{Cognitive pillar}

The centre point of the cognitive pillar is learning through production of new knowledge and it is necessary that this new knowledge hold legitimacy. The cognitive pillar reflects common cultural understandings and awareness based on the best available 
knowledge, but this knowledge must be shared for institutional learning to take place. An important function under this pillar is therefore the ability to communicate this knowledge through to the other pillars through interactions and feedback loops. Legitimacy under the cognitive pillar is essentially measured against what makes sense (Scott and Davis 2014; Scott 2014). The structure of the institution should work to allow the creation of new knowledge, the communication of this knowledge, and then the institution should be flexible enough to adapt to the new knowledge. There is no automatic relationship, however, between the learning by stakeholders and institutional learning; nor is it a given that the institution will adjust or adapt even if the lessons learned by the stakeholders clearly indicate the necessity of such a change (Jentoft 2004).

Iceland

The statistics on MAT activities continually feed new knowledge into the system (Figure 3E), legitimizing the normative pillar (Figure 3A, B). Evidence presented in Solstrand (2013) shows that communication mechanisms for learning and adaptation were working from the bottom up and the top down to mitigate conflicts. The MAT business owners were regularly communicating the problems having to adjust to regulations written for the commercial fishing fleet. This communication took the form of emails, phone calls, and letters to the government officials. The government officials responded timely, sometimes within just a matter of days, with modifications to regulations and laws (Figure 3C). In the span of three years, there were seven modifications to regulations, and two new laws enacted to mitigate conflicts.

For the institution as a whole, having the same regulatory structure as for commercial fisheries makes sense, finding legitimacy within the normative pillar (Figure 3F). Strict control from the regulative pillar is such that there are no doubts around how much fish is being extracted, which also provides legitimacy to the system. Although the business owners expressed frustration with the day-to-day operational problems encountered as a result of the regulations - for example, having to replenish boat quotas for $20+$ boats all summer long - all problems identified during the field visits were resolved through communication in the form of feedback loops. The institutional structure, though rigid in one way, was demonstrating learning and flexibility to adapt.

In interviews, government officials stated that building a robust tourism industry in the Western Fjords is a top priority, and that the regular modifications made to laws and regulations for MAT have reflected this commitment. The feedback loops between business owners and government for MAT are a best practice example of interactive adaptive governance (Jentoft et al. 2010; Solstrand 2013), where conflict resolution and mitigation are taking place through institutional learning and adaptation in a balanced, ongoing process. All four pillars are involved in this process.

Whether or not the tourists themselves share in the cognitive pillar's underpinnings of societal understanding seems to be irrelevant to how MAT functions as an institution, except for one very significant point. The tourists, who are also considered as stakeholders (Solstrand and Gressnes 2014; Solstrand 2014), can communicate their dissatisfaction by not choosing Iceland as a tourist destination. Such communication sends a clear message that perhaps Iceland's institutional system for MAT has too many restrictions that prevent tourists from feeling they are getting the best fishing 
experience for their money. It may also serve as an explanation for why growth is not evident to any great degree. The number of active boats (48) (Table 1), and the number of companies (3) has remained fairly constant over the last four years.

\section{Norway}

The continual process of knowledge acquisition and processing, which subsequently affects institutional learning, is happening via the cognitive pillar. Institutional responsiveness and adaptation are stimulated in both the regulative and normative pillars, if communication mechanisms are in place to transfer the knowledge (Figure 3B, C).

Interview data combined with field observations, participant observations, archival data and media reports were consistent with regard to the cognitive pillar. Communication is blocked. There was no effective dialogue or feedback loops between the camp owners and government officials identified. With the exception of the regulation on minimum size, the regulations have not been modified since 2006 when the $15 \mathrm{~kg}$ export quota was enacted. A common theme in the interviews with camp owners was the lack of communication with government officials. The camp owners have good ideas how to resolve some of the conflicts at the local level, but there are no mechanisms in place for these ideas to be communicated through the system. This is a stressor to the cognitive pillar, preventing the generation of new knowledge, which prevents institutional learning. Essentially, in Figure 3, C, B, and E are blocked.

Applying the test of legitimacy, one must ask if the Norwegian institution for MAT makes sense. Tourists asked one camp owner in Finnmark if they could fish as much as they want. The answer was yes, according to regulations. Over the next two days, four tourists landed everything they caught over minimum size - a total of 1.2 tonnes of fish - equivalent to $150 \mathrm{~kg}$ per day per person. Some fish was given away to local residents, but most of this fish had to be thrown away, because according to the law the fish could not be sold, and could not be exported. Under the cognitive pillar the way that MAT functions as an institution does not make sense, given the way MAT functions in practice - if long-term sustainability of the fish as a resource is the end goal.

In another example, with regard to the trophy fish regulation, what happens when a tourist actually catches one of the prized monster-sized halibut being advertised in the marketing brochures? After all the photos are taken, the fish will likely be dead. Freezing a $175-200 \mathrm{~kg}$ halibut whole and transporting it home in a personal car or camper as a trophy fish is something that all the tourists interviewed deemed highly improbable. Thus, unless the fisher's dream catch is dumped back into the sea, the tourist cannot remain in compliance with Norwegian regulations and do anything responsible with the catch. Example after example emerged in the interviews where the system itself was forcing non-compliance by sport fishers who would have preferred to operate within the regulations. Examples here include the trading of large-sized fish for diesel fuel or accommodations; or fish being sold to local fishers or the camp owner just so the fish would not be wasted. Regulations are stressing the normative pillar (Figure 3F).

As in Iceland, interviews revealed that camp owners are the stakeholders most likely to contribute valuable suggestions to solving some of these conflicts on a more local level, but the mechanisms for communicating their knowledge are not in place. "The 
disempowerment of the community and the erosion of local control is one of the more serious consequences of contemporary resource management with its standardized science and command-and-control practice" (Berkes 2010, p. 23).

Under cognitive evaluation, the latest estimate from Vølstad et al. (2011b) might or might not have provided sufficient/legitimate scientific knowledge to justify keeping the regulations as they are, or to support the conclusion that MAT as an institution is too small to justify the resources required to implement a wide-scale, comprehensive monitoring programme. The estimates bring the question of legitimacy to the foreground because neither side of the argument on how much tourist activities are impacting the stocks can be legitimately backed up by hard facts. Under the cognitive pillar, Norway's management strategy is demonstrative of a type of 'institutional constipation', where new knowledge and communication mechanisms are not flowing through the system correctly. This has the effect of inhibiting the pillars' functionality, and thereby institutional learning, adaptation, and ultimately balance.

\section{Conclusions}

Using marine angling tourism (MAT) in Iceland and Norway as case study examples within the niche sector of consumptive wildlife tourism, this article has demonstrated how the governance of MAT is influenced by institutional structure, conditions, and inter-dynamics. Iceland's Fisheries Management Act and Norway's Marine Resources Act are rooted in the same socio-cultural values that respect and honour the fish as a common pool resource, the marine fishing heritage, and protection of the wild marine living resources for future generations. However, the two countries have developed very different strategies for realising this protection with regard to MAT.

A theoretical model was created to break down the individual elements in the institutional structure, in order to highlight more clearly the inter-connectedness of the four institutional pillars. Such an analysis has demonstrated how labyrinthine the relationship is between the social and ecological dimensions of a complex SES such as consumptive wildlife tourism. Using empirical data on the total seasonal catch, the natural pillar has been shown to play a significant role within the institutional structure, and as such cannot be managed separately from the rest of the institution, or considered separately from the other institutional pillars. The findings from this article reinforce the argument by Berkes that a reconceptualization of natural resource management is needed (Berkes 2010). The institutional analysis presented provides support for the modification of traditional approaches to the management of marine SESs - namely: 1) how to develop complex adaptive systems approaches to deal with SESs for a contextualized understanding of the drivers of change, from local to global levels; and 2) how knowledge production, adaptive management, and social learning for the governance of marine ecosystems can and should work in practice (Berkes 2011).

Consumptive wildlife tourism creates a highly complex, intertwined relationship with the wild living marine resources and host communities. It cannot exist in a bubble of its own design, but affects and is affected by the institutions it sits within - on the regional, national, and international levels. All resource users as stakeholders (Solstrand 2014) share in the right to extract fish as a common pool resource; therefore responsibility and accountability must also be shared by all resource users. A better understanding of these complex institutional inter-dynamics assists in the creation of a more 
effective governance strategy - critical for the long-term sustainability of both the SES as an institution and the vulnerable fish stocks.

\section{Endnotes}

${ }^{a}$ A detailed justification for why these two regions can be compared is found in Solstrand (2013), and therefore will not be repeated here. One of the MAT businesses in Iceland boasts on their website the following: "Fishing on the West part of Iceland can be compared to fishing in northern Norway."

bhttp://www.oxforddictionaries.com/definition/english/conflict. Accessed 14 March 2014.

${ }^{\mathrm{c}}$ Directorate of Fisheries: Cod quota for recreational fishers. Accessed 2 February 2015. http://www.fiskeridir.no/fritidsfiske/salg-av-fangst

${ }^{\mathrm{d}}$ IUCN RedList: http://www.iucnredlist.org/

${ }^{\mathrm{e}}$ From this point forward, Scott (2014) will be used to refer to and include all previous editions of the book titled Institutions and Organizations by Scott.

${ }^{f}$ Oxford Dictionary: http://www.oxforddictionaries.com/definition/english/cognition. Accessed 14 March 2014.

gThese weights represent average ranges, but some individual fish can be much larger.

hNorge 2013 Statistisk Årbok 2013: http://www.ssb.no/aarbok/kart/i.html (Norway's Statistics Yearbook for 2013). Accessed 14 March 2014

${ }^{\mathrm{i}}$ Directorate of Fisheries: http://www.fiskeridir.no/fritidsfiske/salg-av-fangst. Accessed 14 March 2014

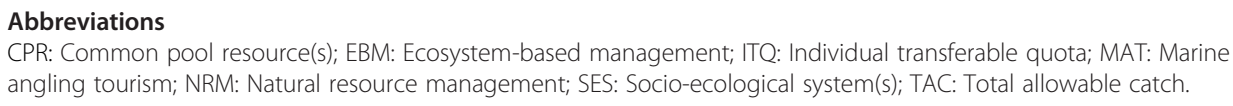

\section{Acknowledgements}

This research was supported by a grant from SpareBank Gavefond Nord-Norge, a gift fund from one of Northern Norway's leading banks. Fieldwork in Iceland was supported by a grant for PhD study abroad through the Faculty of Biosciences, Fisheries and Economics. Sincere gratitude is extended to Professor Jahn Petter Johnsen, and Professor Svein Jentoft - Norwegian College of Fishery Science, UiT - The Arctic University of Norway, for their contributions to earlier drafts of this article.

Received: 14 July 2014 Accepted: 6 February 2015

Published online: 08 April 2015

\section{References}

Alpingi. 1996. Law 57/1996 on the treatement of harvestable marine stocks. Lög um umgengni um nytjastofna sjávar. 1996 Nr. 57 3. juni. Retrieved 9 June 2011 from: http://www.althingi.is/lagas/nuna/1996057.html.

Alpingi. 2011. Law 70/2011 on ammendments to Law nr. 116/2006 on the management of fisheries, with later ammendments. Lög um breytingu á lögum nr. 116/2006, um stjórn fiskveiða, með síðari breytingum (strandveiði, aflamark, samstarf, tekjur af veiðigjaldi, tímabundin ákvæði). Retrieved 9 September 2011 from: http://stjornartidindi. is/Advert.aspx?ID=c04202d9-77ce-47a6-be57-12530da7726c.

Arlinghaus, Robert. 2005. A conceptual framework to identify and understand conflicts in recreational fisheries systems, with implications for sustainable management. Aquatic Resources, Culture and Development 1(2): 145-174.

Arlinghaus, Robert. 2007. Voluntary catch-and-release can generate conflict within the recreational angling community: a qualitative case study of specialised carp, Cyprinus carpio, angling in Germany. Fisheries Management and Ecology 14(2): 161-171. 
Arlinghaus, Robert, Steven J Cooke, Jon Lyman, David Policansky, Alexander Schwab, Cory Suski, Stephen G Sutton, and Eva B Thorstad. 2007. Understanding the Complexity of Catch-and-Release in Recreational Fishing: An Integrative Synthesis of Global Knowledge from Historical, Ethical, Social, and Biological Perspectives. Reviews in Fisheries Science 15(1-2): 75-167. doi:10.1080/10641260601149432.

Bauer, Johannes, and Alexander Herr. 2004. Hunting and fishing tourism - chapter 4. In Wildlife Tourism: Impacts, Management and Planning, ed. Higginbottom Karen. Altona Vic: Common Ground Publishing Pty Ltd.

Berkes, Fikret. 2010. Shifting perspectives on resource management: Resilience and the reconceptualization of 'Natural Resources' and 'Management'. MAST 9(1): 13-40.

Berkes, Fikret. 2011. Restoring Unity: The concept of marine social-ecological systems. In World Fisheries: A social-ecological analysis, eds. Rosemary E. Ommer, R. lan Perry, Kevern Cochrane, and Philippe Cury. Oxford, UK: Wiley-Blackwell.

Berkes, Fikret, and Carl Folke. 1998. Linking social and ecological systems for resilience and sustainability. In Linking Social and Ecological Systems - Management practices and social mechanisms for building resilience, eds. Fikret Berkes, and Carl Folke. Cambridge: Cambridge University Press.

Berkes, Fikret, Johan Colding, and Carl Folke. 2003. Navigating social-ecological systems - building resilience for complexity and change. Cambridge, UK: Cambridge University Press.

Borch, Trude, Mikko Moilanen, and Frank Olsen. 2011. Sjøfisketurisme i Norge - Debatter, Regulering. NORUT: Struktur og Ringvirkninger.

Bramwell, Bill. 2011. Governance, the state and sustainable tourism: a political economy approach. Journal of Sustainable Tourism 19(4-5): 459-477. doi:10.1080/09669582.2011.5767650.

Briassoulis, Helen. 2002. Sustainable tourism and the question of the commons. Annals of Tourism Research 29(4): 1065-1085. doi:10.1016/s0160-7383(02)00021-x.

Briassoulis, Helen, and J van der Straaten. 1992. Tourism and the environment: regional, economic and policy issues. Dordrecht, Netherlands: Kluwer Academic Publishers.

Brown, Thomas C. 1984. The Concept of Value in Resource Allocation. Land Economics 60(3): 231-246. doi:10.2307/3146184.

Budowski, Gerardo. 1976. Tourism and Environmental Conservation: Conflict, Coexistence, or Symbiosis? Environmental Conservation 3(01): 27-31. doi:10.1017/S0376892900017707.

Butler, Richard W. 1974. The social implications of tourist developments. Annals of Tourism Research 2(2): 100-111.

Cap, Gemini, and Young Ernst. 2003. Vurdering av turistfiske some inntektskilde i Norge (Economic impact from marine fishing tourism in Norway). Trondheim: Cap Gemini Ernst and Young.

Coser, Lewis. 1956. The Functions of Social Conflict. New York: The Free Press.

Decrop, Alain. 1999. Triangulation in qualitative tourism research. Tourism Management 20(1): 157-161. doi:10.1016/ S0261-5177(98)00102-2.

Denzin, NK. 1978. The Research Act -, 2nd ed. New York: McGraw Hill.

Denzin, NK, and YS Lincoln. 1994. Entering the field of qualitative research (pp 1-17). In Handbook of qualitative research, ed. NK Denzin and YS Lincoln. Thousand Oaks: Sage.

Farrell, BH, and L Twining-Ward. 2004. Reconceptualizing tourism. Annals of Tourism Research 31(2): 274-295. doi:10.1016/j.annals.2003.12.002.

Ferter, K, Borch Trude, J Kolding, and JH Vølstad. 2013. Angler behaviour and implications for management - catch-and-release among marine angling tourists in Norway. Fisheries Management and Ecology 20(2-3): 137-147. doi:10.1111/j.13652400.2012.00862.x.

Ferter, Keno, Klaas Hartmann, Alf Ring Kleiven, Even Moland, and Esben Moland Olsen. 2015. Catch-and-release of Atlantic cod (Gadus morhua): post-release behaviour of acoustically pretagged fish in a natural marine environment. Can. J. Fish. Aquat. Sci 72: 252-261. dx.doi.org/10.1139/cjfas-2014-0290.

Fevolden, SE, and GH Pogson. 1997. Genetic divergence at the synaptophysin (Syp I) locus among Norwegian coastal and north-east Arctic populations of Atlantic cod. Journal of Fish Biology 51(5): 895-908. doi:10.1111/j.10958649.1997.tb01529.x.

Fiskistofa. 2010. Aflahefti Fiskistofu - Fiskveiđiáriđ 1 sept 2009-31 aug 2010. Reykjavik, Fiskistofa - Directorate of Fisheries. Fiskistofa. 2011. Aflahefti Fiskistofu - Fiskveiđiáriđ 1 sept 2010-31 aug 2011. Reykjavik, Fiskistofa - Directorate of Fisheries. Fiskistofa. 2012. Aflahefti Fiskistofu - Fiskveiđiáriđ 1 sept 2011-31 aug 2012. Reykjavik, Fiskistofa - Directorate of Fisheries. Fiskistofa. 2013. Aflahefti Fiskistofu - Fiskveiđiáriđ 1 sept 2012-31 aug 2013, 12. Reykjavik: Fiskistofa - Directorate of Fisheries. FKD. 2006. FOR 2006-06-01 nr 570: Forskrift om utførselskvote av fisk og fiskevarer fra sportsfiske. Accessed 31 August 2011 from: http://lovdata.no/pro/\#document/SF/forskrift/2006-06-01-570? searchResultContext=1457, ed. Fiskeri- og kystdepartementet.

Folke, Carl. 2007. Social-ecological systems and adaptive governance of the commons. Ecological Research 22(1): 14-15. doi:10.1007/s11284-006-0074-0.

Gössling, Stefan. 2002. Human-environmental relations with tourism. Annals of Tourism Research 29(2): 539-556. doi:10.1016/s0160-7383(01)00069-x.

Hall, C Michael. 2001. Trends in ocean and coastal tourism: the end of the last frontier? Ocean \& Coastal Management 44: 601-618.

Hall, C Michael. 2008. Tourism planning. Policies, processes and relationships. Harlow: Pearson.

Hallenstvedt, Abraham, and Ivar Wulff. 2001. Fisk som Agn. Utenlandsk Turistfiske i Norge (Fish as Bait. Foreign tourist fishing in Norway). Rapport fra et fellesprosjekt Norges Fiskarlag og Norges Turistråd. Tromsø: Norges Fiskerihøgskole/Universitetet i Tromsø.

Hardin, Garrett. 1968. The Tragedy of the Commons. Science 162(3859): 1243-1248.

ICES. 2013. Report of the Arctic Fisheries Working Group (AFWG). ICES CM 2013/ACOM:05. 726 pp. Copenhagen: ICES Headquarters.

Jentoft, Svein. 2000. The community: a missing link of fisheries management. Marine Policy 24(1): 53-60. doi:10.1016/ s0308-597x(99)00009-3.

Jentoft, Svein. 2004. Institutions in fisheries: what they are, what they do, and how they change. Marine Policy 28(2): 137-149. http://dx.doi.org/10.1016/50308-597X(03)00085-X. 
Jentoft, Svein. 2011. Roots and Wings - the need for community in the age of globalization becomes apparent when we employ the double vision of interdisciplinarity to the governance of fisheries. Samudra Report 60: 17-22.

Jentoft, Svein, and Knut H. Mikalsen. 2014. Do national resources have to be centrally managed? Vested interests and institutional reform in Norwegian fisheries governance. Maritime Studies 13 (5). doi:10.1186/2212-9790-13-5.

Jentoft, Svein, Ratana Chuenpagdee, Alida Bundy, and Robin Mahon. 2010. Pyramids and roses: Alternative images for the governance of fisheries systems. Marine Policy 34(6): 1315-1321.

Jick, Todd D. 1979. Mixing Qualitative and Quantitative Methods: Triangulation in Action. Administrative Science Quarterly 24(4): 602-611.

Johnsen, Jahn Petter and Søren Eliasen. 2011. Solving complex fisheries management problems: What the EU can learn from the Nordic experiences of reduction of discards. Marine Policy 35(2): 130-139. http://dx.doi.org/10.1016/j. marpol.2010.08.011.

Johnson, RB. 1999. Appendix A: Examining the Validity Structure of Qualitative Research. In Cases in Qualitative Research: Research Reports for Discussion and Evaluation, ed. K Andrea and Milinki. Los Angeles: Pyrczak Publishing.

Kooiman, Jan, Maarten Bavinck, Svein Jentoft, and Roger Pullin. 2005. Fish for Life: Interactive Governance for Fisheries. In MARE Publicaction Series. Amsterdam: Amsterdam University Press.

Levin, Simon A. 2006. Learning to live in a global commons: socioeconomic challenges for a sustainable environment. Ecological Research 21(3): 328-333. doi:10.1007/s11284-006-0162-1.

Lovelock, Brent. 2008. An introduction to consumptive wildlife tourism. In Tourism and the consumption of wildlife Hunting, shooting and sport fishing, ed. Lovelock Brent, 290. London and New York: Routledge Taylor Francis Group; Contemporary geographies of leisure, tourism and mobility.

McCay Bonnie J, James M Acheson. 1987. Human ecology of the commons. In The question of the commons: the culture and ecology of communal resources, eds. Bonnie J. McCay and James M. Acheson, 1-34. Tuscon, AZ: University of Arizona Press.

McKercher, Bob. 1993. Some fundamental truths about tourism. Understanding tourism's social and environmental impacts. Journal of Sustainable Tourism 1(1): 6-16.

MFCA. 2008. LOV 2008-06-06 nr 37. Lov om forvaltning av viltlevande marine ressursar (havressurslova). Act on the management of wild living marine resources (Marine Resources Act) Retrieved 30 august 2012 from: https:// lovdata.no/dokument/NL/lov/2008-06-06-37. Ministry of Fisheries and Coastal Affairs.

Ommer, Rosemary E., and R. lan Perry. 2011. Social-ecological systems in fisheries - Introduction. In: World Fisheries: A Social-Ecological Analysis, ed(s). Rosemary E. Ommer, R. Ian Perry, Kevern Cochrane, Philippe Cury, 1-8, Fish and Aquatic Resources Series 14, Series Ed Tony J. Pitcher. Wiley-Blackwell Publishing Ltd.

Oppermann, Martin. 2000. Triangulation - a methodological discussion. International Journal of Tourism Research 2(2): 141-145. doi:10.1002/(SICI)1522-1970(200003/04)2:2<141::AID-JTR217>3.0.CO;2-U.

Ostrom, Elinor. 1990. Governing the Commons: The Evolution of Institutions for Collective Action. New York: Cambridge University Press.

Ostrom, Elinor. 2009. A General Framework for Analyzing Sustainability of Social-Ecological Systems. Science 325 (24 July 2009). doi:10.1126/science.1172133.

Ostrom, Elinor, J Burger, CB Field, R Norgaard, and D Policansky. 1999. Revisiting the commons: Local lessons, global challenges. Science 284: 278-282.

Pascual-Fernandez, Jose J, Svein Jentoft, Jan Kooiman, and Abbie Trinidad. 2005. Institutions for fisheries governance Institutional Linkages. In Fish for Life - Interactive Governance for Fisheries, ed. Jan Kooiman, Maarten Bavinck, Svein Jentoft, and Roger Pullin, 217-238. Amsterdam: Amsterdam University Press.

Pitcher Tony J, Daniela Kalikoski, Katherine Short, Divya Varkey, Ganapathiraju Pramod. 2009. An evaluation of progress in implementing ecosystem-based management of fisheries in 33 countries. Marine Policy 33(2): 223-232. http://dx. doi.org/10.1016/j.marpol.2008.06.002.

Pitcher Tony J, Kalikoski D, Pramod G, editors. Evaluations of compliance with the UN code of conduct for responsible fisheries. Fisheries Centre research reports, vol. 14(2), 2006, 1191. Also available at: http://www.fisheries.ubc.ca/ publications/reports/report14_2.phpS.

Pogson, Grant H, and Svein-Erik Fevolden. 2003. Natural selection and the genetic differentiation of coastal and Arctic populations of the Atlantic cod in northern Norway: a test involving nucleotide sequence variation at the pantophysin (Panl) locus. Molecular Ecology 12(1): 63-74. doi:10.1046/j.1365-294X.2003.01713.X.

Pruitt, Dean G. 1998. Social Conflict. In: Handbook of Social Psychology Volume 2, Fourth Edition, Eds Daniel T. Gilbert, Susan T Fiske and Gardner Lindzey McGraw-Hill, USA, 1998, p.470-503.

Robinson, Mike. 1999. Cultural conflicts in tourism: Inevitability and inequality. In Tourism and cultural conflicts, ed. Robinson Mike and Boniface Priscilla, 314. Oxfordshire: CABI International.

Rohner, Ronald P. 1977. Advantages of the comparative method of anthropology. Behavior Science Research 12: 117144.

Scott, W. Richard. 1995. Institutions and Organizations. London: Sage Publications.

Scott, W. Richard. 2008. Institutions and Organizations: Ideas and Interests, 3rd ed. Thousand Oaks, CA: Sage.

Scott, W. Richard. 2014. Institutions and Organizations: Ideas, Interests and Identities, 4th ed. Thousand Oaks, CA: Sage Publications Inc

Scott, W. Richard, and Gerald F Davis. 2014. Organizations and Organizing Rational, Natural and Open Systems Perspectives. Essex, UK: Pearson.

Smith, JA, P Flowers, and M Larkin. 2009. Interpretative Phenomenological Analysis - Theory, Method and Research. London: Sage.

Solstrand, Maria-Victoria. 2013. Marine angling tourism in Norway and Iceland: Finding balance in management policy for sustainability. Natural Resources Forum 37(2): 113-126. doi:10.1111/1477-8947.12006.

Solstrand, Maria-Victoria. 2014. Marine tourism fisheries - Challenges of governance and governability - Northern Norway as a case study. Doctoral thesis 17-Dec-2014. UIT The Arctic University of Norway, Tromsø, Norway. http:// munin.uit.no/bitstream/handle/10037/7001/thesis.pdf?sequence $=3$. 
Solstrand, Maria Victoria, and Thomas Gressnes. 2014. Marine angling tourist behavior, non-compliance, and implications for natural resource management. Tourism Management 45: 59-70. http://dx.doi.org/10.1016/j. tourman.2014.03.014.

Strange, David, and Weslely D Sine. 2002. Interorganizational institutions. In The Blackwell Companion to Organizations, ed. Joel AC Baum, 497-519. Oxford, UK: Blackwell.

Vølstad, JH, K Ferter, M Hauge, K Nedreaas, and M Nilsen. 2011 a. Hva betyr fisketurismen for de lokale fiskebestandene langs kysten? In Havforskningsrapporten, 58-61. vol. Fisken og havet 1-2011: Havforskningsinstituttet.

Vølstad, JH, K Korsbrekke, KH Nedreaas, M Nilsen, GN Nilsson, M Pennington, S Subbey, and R Wienerroither. $2011 \mathrm{~b}$ Probability-based surveying using self-sampling to estimate catch and effort in Norway's coastal tourist fishery. ICES Journal of Marine Science: Journal du Conseil 68(8): 1785-1791. doi:10.1093/icesjms/fsr077.

Ward, T, D Tarte, E Hegerl, and K Short. 2002. Policy proposals and operational guidance for ecosystem-based management of marine capture fisheries. Sydney, Australia: World Wide Fund for Nature.

Yang, Jingjing, Chris Ryan, and Lingyun Zhang. 2013. Social conflict in communities impacted by tourism. Tourism Management 35: 82-93. http://dx.doi.org/10.1016/j.tourman.2012.06.002.

Yin, Robert K. 2009. Case Study Research Design and Methods - Fourth Edition, Applied Social Research Methods Series. Los Angeles, London: Sage.

Submit your manuscript to a SpringerOpen ${ }^{\circ}$ journal and benefit from:

- Convenient online submission

- Rigorous peer review

- Immediate publication on acceptance

Open access: articles freely available online

- High visibility within the field

- Retaining the copyright to your article

Submit your next manuscript at $>$ springeropen.com 